\title{
Erosive pustular dermatosis of the scalp successfully treated with oral prednisone and topical tacrolimus
}

\author{
Dermatose pustular erosiva do couro cabeludo tratada com sucesso com \\ prednisona oral e tacrolimus tópico
}

\author{
Mariana Ribas Zahdi ${ }^{1}$ \\ Vanessa Cristina Soares ${ }^{2}$ \\ Fabiane Andrade Mulinari-Brenner ${ }^{3}$
}

\author{
Gabriela Bestani Seidel ${ }^{2}$ \\ Camila Fernanda Novak Pinheiro de Freitas ${ }^{1}$
}

DOI: http://dx.doi.org/10.1590/abd1806-4841.20132109

\begin{abstract}
Erosive pustular dermatosis of the scalp is a rare inflammatory disorder of the scalp, affecting elderly patients after local trauma and leading to scarring or cicatricial alopecia. Case Report: An elderly female patient complained of painful pustules on the parietal region bilaterally with progressive enlargement and ulceration. A biopsy suggested erosive pustular dermatosis of the scalp and the patient was treated with prednisone 40 $\mathrm{mg} /$ day and $0.1 \%$ topical tacrolimus. After 10 weeks complete closure of the eroded areas was observed and a stable scarring alopecia developed.
\end{abstract}

Keywords: Alopecia; Cicatrix; Scalp; Scalp dermatoses

Resumo: A dermatose pustular erosiva do couro cabeludo é uma doença inflamatória rara do couro cabeludo, de ocorrência preferencial em pacientes idosos após trauma local e com evolução para alopecia cicatricial. O caso relatado é de uma paciente idosa feminina que iniciou com pústulas dolorosas em região parietal bilateral com aumento das lesões e exulceração local. Após o diagnóstico histológico de dermatose pustular erosiva do couro cabeludo, foi iniciada prednisona $40 \mathrm{mg} /$ dia e tacrolimus 0,1\% tópico. Após 10 semanas evoluiu com cicatrização completa das áreas erosadas e alopecia cicatricial.

Palavras-chave: Alopecia; Cicatriz; Couro cabeludo; Dermatoses do couro cabeludo

\section{INTRODUCTION}

Erosive pustular dermatosis of the scalp (EPDS) is a rare inflammatory disease of unknown etiology that usually affects older people, especially white women. ${ }^{1}$ No reports of this disease have been previously published in the Brazilian literature.

\section{CASE REPORT}

A 68-year- old white female complained of itching and burning sensation on the scalp that started in October 2010. Erythematous papules and painful pustules developed in the right parietal area and progressed to the left side. She had previous his- tory of hypertension, diabetes and hyperthyroidism. She also reported two prior cranial traumas.

She was diagnosed as having a bacterial skin infection by the primary care physician $(\mathrm{PCP})$, who prescribed cephalexin.

No improvement was observed after a couple of weeks and the PCP considered the diagnosis of herpes zoster. She was treated with oral acyclovir, with no response.

She was referred to a dermatology center in May 2011. A progressive erosion was seen on both parietal areas, with pustules and scarring alopecia (Figure 1).

\footnotetext{
Received on 05.09.2012.

Approved by the Advisory Board and accepted for publication on 08.10.2012.

* Work performed at the Serviço de Dermatologia, Hospital de Clínicas da Universidade Federal do Paraná (HC-UFPR) - Curitiba, PR, Brazil.

Financial Support: none

Conflict of Interests: none

Dermatology Resident, Teaching Hospital, Federal University of Paraná (Hospital de Clínicas, Universidade Federal do Paraná), Curitiba, (PR), Brazil. Dermatology Fellow, Teaching Hospital, Federal University of Paraná (Hospital de Clínicas, Universidade Federal do Paraná), Curitiba, (PR), Brazil.

Dermatologist, Master of Science in Internal Medicine, Assistant Professor of Dermatology, Federal University of Paraná (Universidade Federal do Paraná), Curitiba, (PR), Brazil. 
She had normochromic normocytic anemia, mild leukocytosis and thrombocytosis, an ESR of 111 $\mathrm{mm}$ and CRP $44 \mathrm{mg} / 1$. Bacterial cultures from the scalp discharge showed multisensitive Staphylococcus aureus.

Histology demonstrated dermal edema and thickening of collagen with mixed inflammatory infiltrate and hemorrhage foci (Figure 2).

The non-specific findings suggested the diagnosis of erosive pustular dermatosis of the scalp. Prednisone $40 \mathrm{mg} /$ day was prescribed,with dramatic improvement and reduction of erosion (Figure 3). When the steroid was tapered there was an increase in purulent discharge (Figure 4). A new course of prednisone was introduced associated with $0.1 \%$ topical tacrolimus, with complete closure of erosions after 10 weeks, leading to a permanent scarring alopecia with telangiectasias on the affected sites (Figure 5). With the use of topical tacrolimus, it was possible to taper the dose of prednisone steadily.

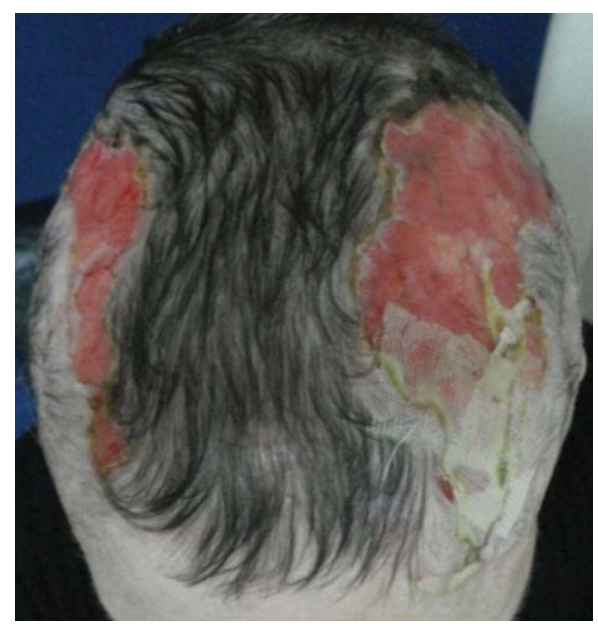

Figure 1:

Clinical aspect on the first visit. Two erosions on both parietal areas with purulent discharge

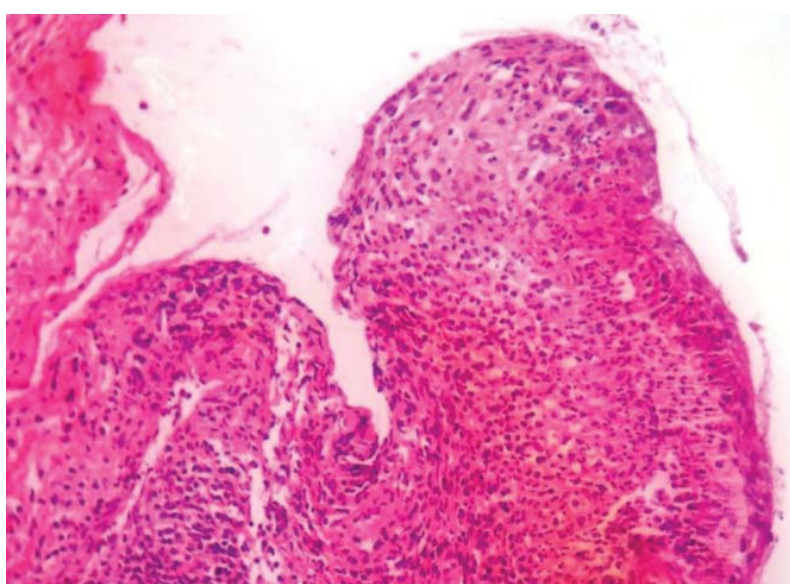

FIGURE 2: A scalp biopsy demonstrated dermal edema, thickening of the collagen bundles and mixed inflammatory infiltrate

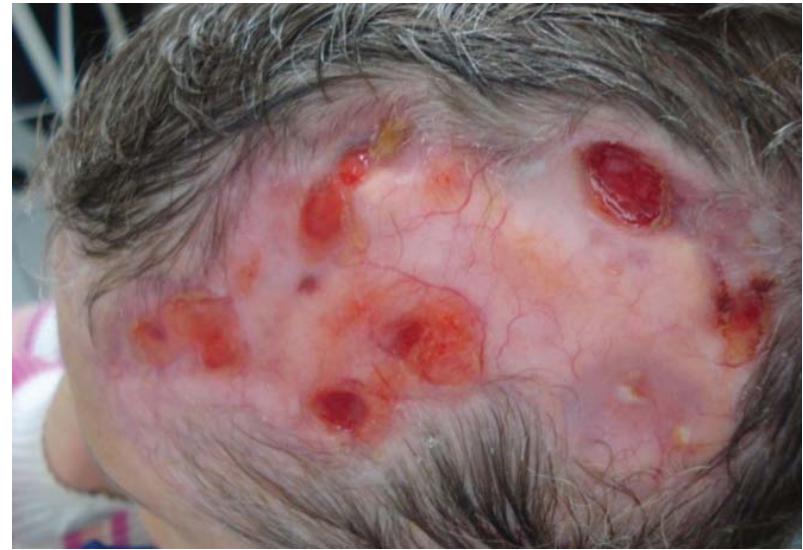

FIGURE 3: Progressive healing with remaining ulcerated areas and apparent telangiectasia

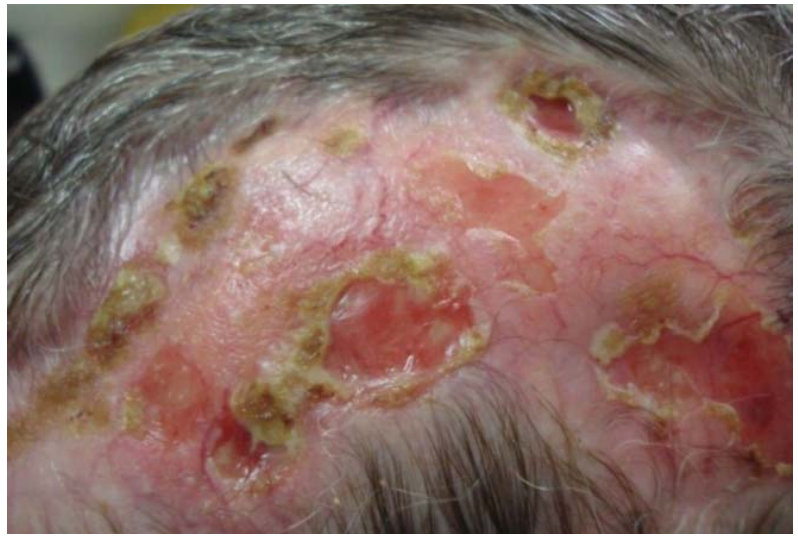

FIGURE 4: Increase discharge after steroid tapering
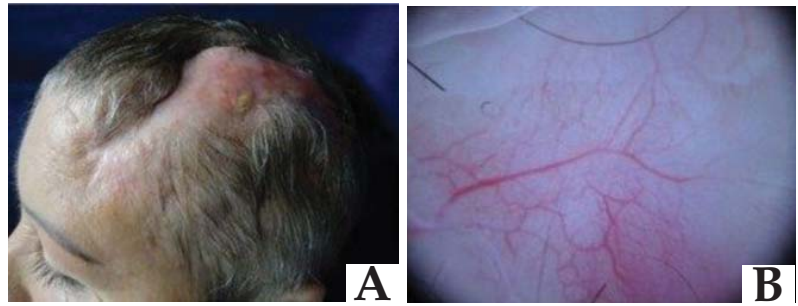

FIGURE 5: A. Final clinical appearance. Scarring alopecia and telangiectasia in the affected sites. B.Dermoscopic appearance of telangiectasia

\section{DISCUSSION}

Erosive pustular dermatosis of the scalp was first described in 1977 by Burton and in 1979 by Pye et $a l^{2,3}$ The pathogenesis is unknown, but factors such as local trauma, topical 5-fluorouracil, surgery, cryotherapy, radiotherapy, laser treatment, irritant contact dermatitis, imiquimod, herpes zoster and prolonged exposure to ultraviolet radiation were suggested as triggers. ${ }^{4,5,67}$ Association with autoimmune diseases 
like rheumatoid arthritis, autoimmune hepatitis, Hashimoto's thyroiditis and Takayasu arteritis have been reported. ${ }^{4}$ The patient had two episodes of local trauma in different time periods and suspicion of herpes zoster, which may have been triggering factors. Hyperthyroidism was not previously reported, but it is also an autoimmune disease presented by the patient.

The disease begins with painful pustules on the scalp, which evolve into erosions covered by crusts. The course is slow and progressive. ${ }^{8}$ In months or years, it may affect large areas, causing cicatricial alopecia. ${ }^{1}$

Usually the initial pustules are sterile. ${ }^{8}$ However, many patients present bacteria and / or fungi isolated from lesions. S. aureus is the most common microorganism found, representing secondary colonization rather than primary infection, confirming failure when treating with antibiotics and antifungals. ${ }^{1}$ Laboratory tests are usually normal, except for an increase in inflammatory markers. There may be positive antibodies for autoimmune diseases. ${ }^{8}$ Patient hematological changes are justified by the chronicity of the condition.

Histology is not a diagnosis. The epidermis may be normal, with hyperkeratosis and parakeratosis, erosion or atrophy, with or without edema and occasional subcorneal pustules. ${ }^{8,9}$ The dermis may

\section{REFERENCES}

1. Caputo R, Veraldi S. Erosive pustular dermatoses of the scalp. J Am Acad Dermatol. 1993;28:96-8.

2. Burt JL. Case for diagnosis: pustular dermatosis of scalp. Br J Dermatol. 1977; 97:S67-9.

3. Pye, RJ, Peachey RD, Burton JL. Erosive pustular dermatosis of the scalp. Br J Dermatol. 1979;100:559-66.

4. Vaccaro M, Guarneri C, Barbuzza 0, Guarneri B. Erosive pustular dermatosis of the scalp: an uncommon condition typical of elderly patients. J Am Geriatr Soc. 2008;56:761-2.

5. Vaccaro M, Barbuzza 0, Guarneri B. Erosive pustular dermatosis of the scalp following treatment with topical imiquimod for actinic keratosis. Arch Dermatol. 2009;145:1340-1.

6. Parodi A, Ciaccio M, Rebora A. Erosive pustular dermatosis of the scalp. Int J Dermatol. 1990;29:517-8.

7. Darwich E, Muñoz-Santos C, Mascaró JM Jr. Erosive pustular dermatosis of the scalp responding to acitretin. Arch Dermatol. 2011;147:252-3.

8. Mastroianni A, Cota C, Ardigò M, Minutilli E, Berardesca E. Erosive pustular dermatosis of the scalp: a case report and review of the literature. Dermatology. 2005;211:273-6.

9. Allevato M, Clerc C, del Sel JM, Donatti L, Cabrera H, Juárez M. Erosive pustular dermatosis of the scalp. Int J Dermatol. 2009;48:1213-6.

10. Peterson B0, Bygum A. Erosive pustular dermatosis of the scalp: a case treated successfully with isotretinoin. Acta DermVenereol. 2008;88:300-1. contain a chronic inflammatory infiltrate of lymphocytes and plasma cells between neutrophils, especially in the upper dermis ${ }^{4,9}$ Foci of phagocytosis and giant cells can be seen around the hair shaft in the deep dermis, where the follicles are destroyed. In later stages, dermal fibrosis and atrophy of hair follicles, with loss of elastic tissue can be seen. ${ }^{8}$

Differential diagnosis includes neutrophilic cicatricial alopecias, fungal and bacterial infections, pustular psoriasis, pyoderma gangrenosum, pemphigus foliaceus, dermatitis artefacta and squamous cell carcinoma. ${ }^{4.5}$ EPDS presents no pathognomonic laboratory and histopathological findings, it is an clinical diagnosis of exclusion . The finding of pustules, erosions and crusts on the scalp of elderly patients, with nonspecific histology, absence of microorganisms and resistance to antibiotics leading to scarring alopecia allows the diagnosis. ${ }^{4}$

A good response to potent topical corticosteroids is reported, however relapses after discontinuation are common. ${ }^{10}$ Alternative effective treatments include oral isotretinoin, zinc sulfate, nimesulide, topical calcipotriol or tacrolimus, dapsone and steroids. ${ }^{9}$ The patient had significant improvement with the use of prednisone, relapsing after discontinuation. The steroid could be tapered after combination with topical tacrolimus.

\author{
MAILING ADDRESS: \\ Mariana Ribas Zahdi \\ Rua Martim Afonso, 1918, Apt. 121 - Bigorrilho \\ 80730-030 Curitiba - PR \\ Brazil \\ E-mail: marianazahdi@yahoo.com.br
}

How to cite this article: Zahdi MR, Seidel GB, Soares VC, Freitas CFNP, Mulinari-Brenner FA. Erosive pustular dermatosis of the scalp successfully treated with oral prednisone and topical tacrolimus. An Bras Dermatol. 2013;88(5):796-8. 